\title{
Presidential Approval in a Context of Political and Institutional Change: The Uruguayan Case
}

\author{
Lucía Selios \\ University of the Republic
}

\begin{abstract}
Do Uruguayan evaluate their presidents according to the cyclical model of approval typical of presidential systems with fixed terms of office? The cyclical model of approval implies that terms of office begin with a "honeymoon" with high levels of approval, then decrease and recover again at the end of the period. In Uruguay, this pattern is found only in the last four governments, but not before periods. How can the changes in the presidential approval dynamics be explained? The article states that this is the result of the changes of electoral rules. Using data from the Executive Approval Project, the temporal analysis reveals that, under the new institutional contexts, popular support for the president grows, increasing the "clarity of responsibility" that allows citizens to evaluate their presidents according to the outcome of economic policies and the electoral cycle. In short, by analyzing the Uruguayan case, this article attempts to provide evidence regarding the importance of institutional design in the approval of the presidential administration.
\end{abstract}

Keywords: public opinion, presidential approval, political institutions

\section{INTRODUCTION}

The study of presidential evaluation is important for understanding the operation of democracies. In presidential systems, if there is an adequate clarity of responsibility, the chief executive is seen as the main responsible for the successes and failures of a government's management, so the variation in the opinions of citizens operates as a mechanism of vertical inter-electoral accountability (O'Donnell, 2007). The sharp drops in approval levels, for example, have a direct impact on changes in electoral preferences, as well as on the directions of government agendas (Carlin, Love \& Martínez-Gallardo, 2015a) and are fairly reliable predictors of presidential term interruptions (Pérez-Liñán, 2007).

In Uruguay, there are few articles that analyze the causes of presidential approval. The few papers available show that as is theoretically expected, approval ratings depend on the economic situation the country is going through (Rius, 1992; Luna, 2002; Carlin \& Hunt, 2015). However, the approval dynamics during government administrations have not yet been studied, so the first questions leading this paper are: how are presidents evaluated during their terms in office in Uruguay?

Have they maintained similar approval ratings over time? Do they follow the cyclical model of approval typical of fixed-term presidential systems?

In a recent paper regarding approval in Latin America, Carlin, Hartlyn, Hellwig, Love, MartínezGallardo \& Singer (2018) state that in presidential systems with fixed terms it is usual to find that approval follows a cyclical model, with high levels of initial support, associated with the "honeymoon" phenomenon, gradual decline and subsequent recovery of approval ratings towards the end of the term. But they find that 
this situation has not always been the case, and evidence several atypical cases or outliers, including the first three presidential terms after 1985 in Uruguay.

When analyzing the approval series in that country, the diagnosis is correct, the cyclical pattern does not emerge until the administration that began in 2000 and the approval averages are very low. For this reason, it can be quickly answered that in Uruguay government performance has not always been evaluated according to the cyclical approval model. So how do we explain the changes in the levels and dynamics of presidential approval during the periods of government?

A large volume of literature argues that institutions whether electoral rules or typical features of a political system have an impact on the way in which citizens evaluate presidents, because they can grant them more popular support and thus favor or hinder clarity of responsibility ${ }^{1}$, in other words, the ability of citizens to clarify the political responsibility of their representatives, particularly of the president (Powell and Whitten, 1992).

The literature also states that institutions modify the clarity of responsibility, as they alter the way in which power is divided, in particular of the importance of veto players in the political system (Carlin et al., 2015a). Thus, for example, if government controls the majority of seats in the legislative branch, it will tend to be held responsible for the welfare of the population, while this responsibility may be diluted if the majority of the parliament is controlled by the opposition. The same situation applies to the powers of the president or the number of parties that form the governing coalition and even the percentage of votes with which the president is elected. Thus, the existence of bicameral parliaments, coalition governments, minority governments and even different levels of political and economic decentralization (León, 2010) can dilute the ability of citizens to hold their rulers accountable.

This observational type of work is limited to describe and argue ${ }^{2}$ that the changes registered in the presidential evaluation series in Uruguay, both in the support level and in the temporal dynamics, are due to changes in the institutional context that took place at the beginning of the 21 st century in the country, particularly in the electoral and party system. It is understood that institutional changes affected approval ratings by modifying the way in which citizens support and are able to assign responsibility for the results of policies to the president, generating changes in the predictors of presidential approval ratings.

Through the Uruguayan case, the article provides a first approach to the relationship between approval dynamics and political institutions in the country. To this end, it begins with a description of the institutional and political changes in Uruguay and analyzes how they impacted presidential approval ratings. The paper proposes an interpretative framework on how institutions affect approval dynamics, using the concepts of clarity of responsibility and economic voting. Subsequently, the methodological specifications are described, followed by an explanation of the changes in the dynamics of presidential approval, according to the impact of the economy, the government cycle and the electoral support of the president before and after the institutional change. The paper ends with some reflections on institutional design and presidential approval, suggesting some alternatives and thinking about the approval dynamics for future government administrations.

\section{Institutional Design, Approval and After}

Uruguay's democracy is one of the oldest and highest positioned in the continent (The Polity IV, Freedom House). It is a presidential system, with fixed terms of 5 years and no immediate reelection. Unlike other "third wave" democracies, it has long-lived parties, an institutionalized and internally fragmented party system, strong party discipline and low levels of corruption. Political competition is ordered by the ideological distinction of the left-right axis and public opinion displays a high support level and evaluation of democracy, and it has a state-centered model born at the beginning of the twentieth century. But the structural problems of emerging democracies, such as economic and social inequality, slow inclusion of women in politics, historical practices of cronyism and patronage, among others, are not alien to it. This combination of characteristics makes the country an attractive case for analyzing the importance of institutions and contexts in public opinion, particularly in the ways in which citizens evaluate their presidents, linked to the institutional context. 
In particular, since 1985, after the last military dictatorship, the country went through a fast transition to recover, in a very short period of time, its political system. During the following 30 years, democratic levels, moderate ideological polarization and gradual change of electoral preferences have been maintained (Luján \& López, 2015). Meanwhile, in these years, public opinion has presented high and stable levels of partisan identification, institutional trust and support for democracy (Vario \& Rodríguez, 2017). In addition, the three main political parties (Colorado Party, National Party and Broad Front) have alternated in government.

When analyzing the presidential approval series (Figure 1), it can be seen that the first administrations did not register the "honeymoon" phenomenon, nor did they follow a specific pattern of variation. This period includes the post-dictatorship governments of the Colorado Party (Julio María Sanguinetti - 9851990), ${ }^{3}$ the National Party (Luis Alberto Lacalle - 1990-1995) and the second government of Julio María Sanguinetti (1995-2000), of the Colorado Party. In contrast, subsequent government administrations do show the cyclical dynamics of approval, particularly the one headed by Jorge Batlle (2000-2005) of the Colorado Party and the following three periods of the Broad Front, Tabaré Vázquez (2005-2010), José Mujica (2010-2015) and again Tabaré Vázquez (2015 to date). The change in the approval pattern is related to the changes in the political-institutional context that occurred at the beginning of the 21 st century. Specifically, a change in the electoral rules governing since the 1999 election and the consolidation of a new balance in the party system (Buquet and Piñeiro, 2014).

Analyses of presidential approval in Uruguay have been limited and their analytical perspectives differ, but all of them highlight the importance of the economy as a predictor of presidential approval ratings. The first two studies (Rius, 1992; Luna, 2002) use annual aggregate data, macroeconomic variables and also subjective variables to establish predictors of approval ratings. They study periods prior to the change in the dynamics of presidential approval in the country. Both find the relevance that the economic situation has on the evaluation. Luna states the following: "At the aggregate level, public opinion responses consistently to objective conditions in the economy" (2002:148), in particular, to inflation and unemployment. ${ }^{5}$

\section{FIGURE 1 \\ EVOLUTION OF PRESIDENTIAL APPROVAL IN URUGUAY ACCORDING TO GOVERNMENT PERIODS (1986-2016 BY QUARTERS)}

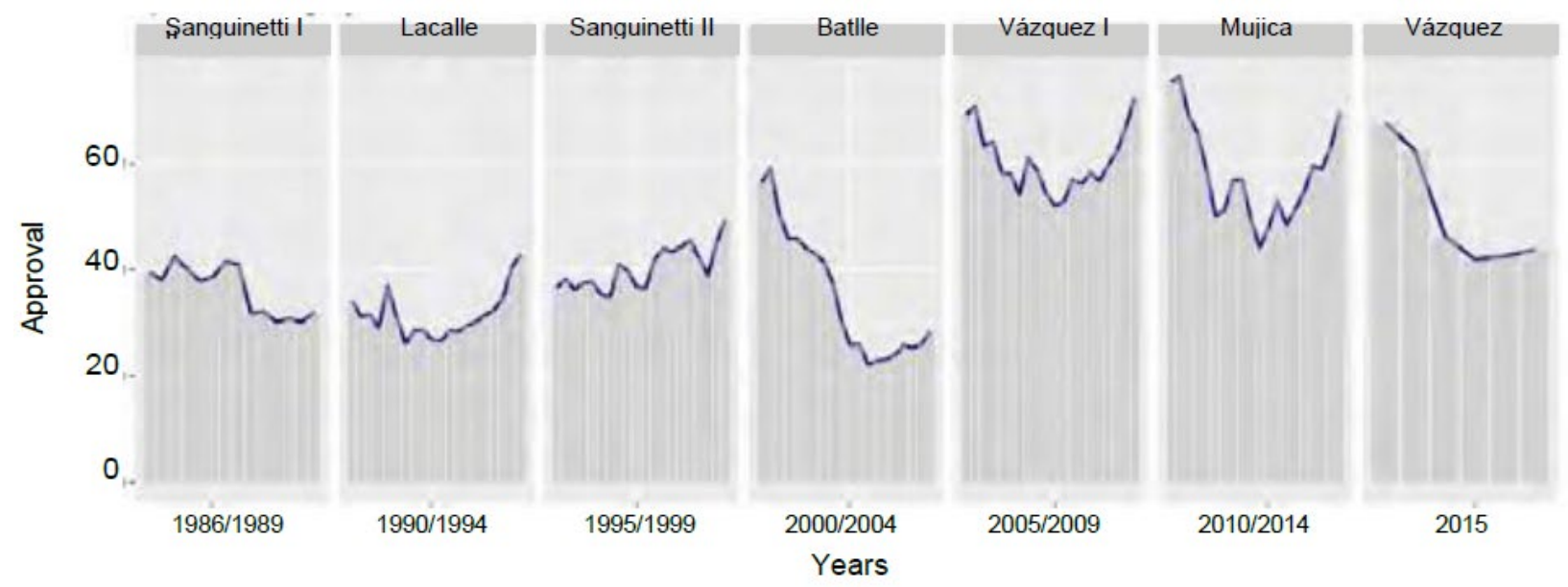

Source: Quarterly approval data are from the Executive Approval Project period 1986-2016.

The other paper, Carlin and Hunt (2015) finds that Uruguayans behave like investors when evaluating their president, in other words, they project their egocentric (personal) economic perspectives before retrospective ones to the presidential evaluation. These authors carried out analyses with individual data after the year 2000, when the presidential evaluation assumes the cyclical model of approval typical of 
presidential regimes, so perhaps their finding is related to the change in the economic predictors of approval linked to the new institutional design.

\section{Constitutional Reform and Presidential Approval}

Uruguay is characterized for being a presidential system with a bicameral parliament, with concurrent elections occurring every five years where immediate reelection is not allowed. Voting is compulsory and the parties or "slogans" present blocked and closed lists to different bodies on a single ballot paper. In addition, in terms of direct democracy, Uruguay has several referendum and plebiscite mechanisms, both by legislative and popular initiative. A constitution was approved by plebiscite in 1996 and promulgated in 1997, the rules of which were applied for the 1999 election and the elected administration that took office in 2000 .

The new regulations introduced several electoral and governance changes. Regarding the government, the reform focused power on the president and gave him/her even more initiative when it came to influencing the legislative agenda and the creation of political agreements. ${ }^{6}$ But the most important change occurred at the electoral level. The new rules separated the election of subnational bodies by six months from the national elections. ${ }^{7}$ In addition, mandatory internal elections were established for the parties, where citizens can voluntarily vote for the candidates of the parties of their choice. In addition, the reform also introduced the presidential run-off election, which must be called if none of the presidential formulas ${ }^{8}$ exceeds half plus one of the total votes cast (including blank and void votes). Both measures, the internal elections and the ballot, made the candidate for president and vice-president be supported by a clear majority of the electorate, a fact that did not happen before the application of the rule.

The modification of the method of electing candidates to the presidency was a fundamental change compared to the previous system. In the past, citizens voted by parties or slogans, within it by sub-mottos or sectors, each with its own candidates for president. In this way, the presidential ticket of the most voted sub-motto within the winning party was the winner. ${ }^{9}$ As a result, the popular vote that each president had in many cases did not exceed $20 \%$ of the electorate, and sometimes he/she even had a lower percentage than other candidates from less voted parties ${ }^{10}$ (Table 1). This fact may explain why from the 1999 election onwards the terms of office begin with a honeymoon, a fact that is not registered before this electoral reform.

TABLE 1

PERCENTAGE OF VOTES OBTAINED BY THE WINNING AND LOSING PRESIDENTIAL TICKET 1984-2014

\begin{tabular}{|c|c|c|c|}
\hline & Winner & Balloting & \% Initial presidential approval \\
\hline 1984 & 31.4 & - & 31.4 \\
\hline 1989 & 38.9 & - & 34.1 \\
\hline 1994 & 24.7 & - & 37.7 \\
\hline 1999 & 40.1 & 54.1 & 56.3 \\
\hline 2004 & 51.7 & - & 69.1 \\
\hline 2009 & 49.3 & 54.6 & 75.3 \\
\hline 2014 & 49.4 & 56.50 & 67.7 \\
\hline
\end{tabular}

Source: Electoral results systematized in Political and International Relations Database FCS-UdelaR. "Results by electoral formula 1971-2009" Valid votes. In balloting, the votes cast are reflected (to improve comparability).

As the last column of Table 1 clearly shows, the initial approval ratings in the first months of the term of office were lower when the electoral flow of the presidential formula was also lower (before the reform). This changes in subsequent presidential terms. There, approval is higher, as well as the voting percentage obtained by the presidential ticket in both the first and second round of elections. 


\section{Evolution of the Party System and Presidential Approval}

The Uruguayan party system is long-lived and institutionalized; in fact, the two main "foundational" or "traditional" parties are more than 180 years old (Blanco or National and Colorado) and the Broad Front appeared almost half a century ago (in 1971). However, in recent political history, since $1985{ }^{11}$ the party system has experienced a major transformation. The gradual decrease in electoral support for the traditional parties (first and second parties until 1994) resulted in an increase in the electoral strength of the Broad Front, an ideologically challenging competitor of the founding parties. The electoral evolution seen as political blocs shows how the traditional subsystem gives way to a growing electoral capitalization of the Broad Front that ends up finding its equilibrium in the 2004 election (Figure 2).

This rebalancing of the party system was reflected in the drop of electoral volatility (Table 2). At the same time, it consolidated the competitive logic between two political blocs, one formed by the founding parties and the other by the Broad Front. If we analyze the approval ratings of the period and the levels of election inter-party and inter-bloc volatility (Figures 3 and 4), it does not seem to exist for the case of the parties, but with the exception of Batlle administration, there is a clear relationship between low volatility and political blocs and presidential approval ratings.

\section{FIGURE 2}

\section{EVOLUTION OF ELECTORAL PREFERENCES ACCORDING TO POLITICAL PARTIES/BLOCS. 1984-2014}

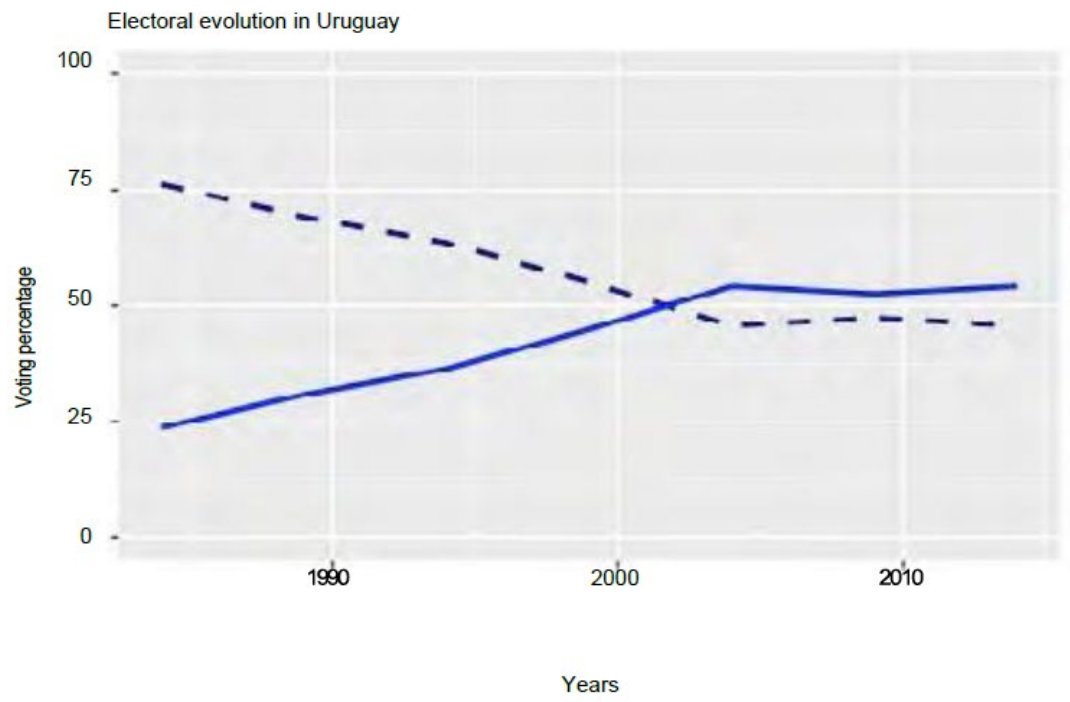

**References: The dotted line corresponds to the electoral support of the so-called Foundational Bloc, composed by adding the electoral results of the National Party and the Colorado Party. The electoral growth of the Broad Front continues to be in line with this trend.

Source: Electoral results systematized in Political and International Relations Database FCS-UdelaR. 
FIGURE 3

PRESIDENTIAL AVERAGE APPROVAL RATINGS DURING THE PERIOD OF GOVERNMENT AND INTER-PARTY AND INTER-BLOC VOLATILITY ${ }^{12}$

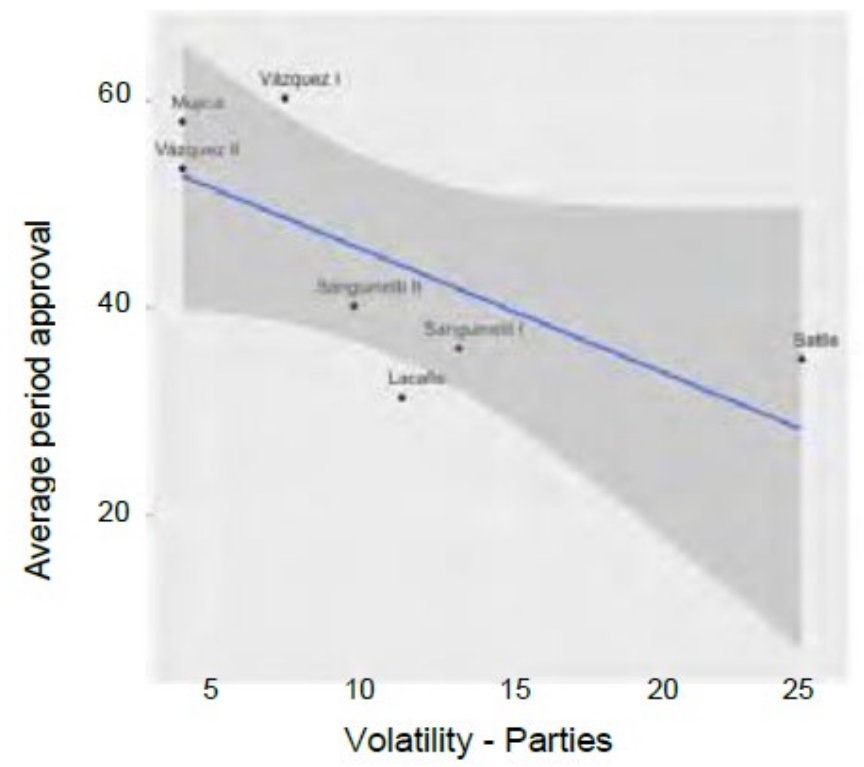

Source: Developed by author, volatility data. Annual approval data correspond to the Executive Approval Project, period 1986-2016, averaged by government period.

FIGURE 4

PRESIDENTIAL AVERAGE APPROVAL RATINGS DURING THE PERIOD OF GOVERNMENT AND INTER-PARTY AND INTER-BLOC VOLATILITY ${ }^{13}$

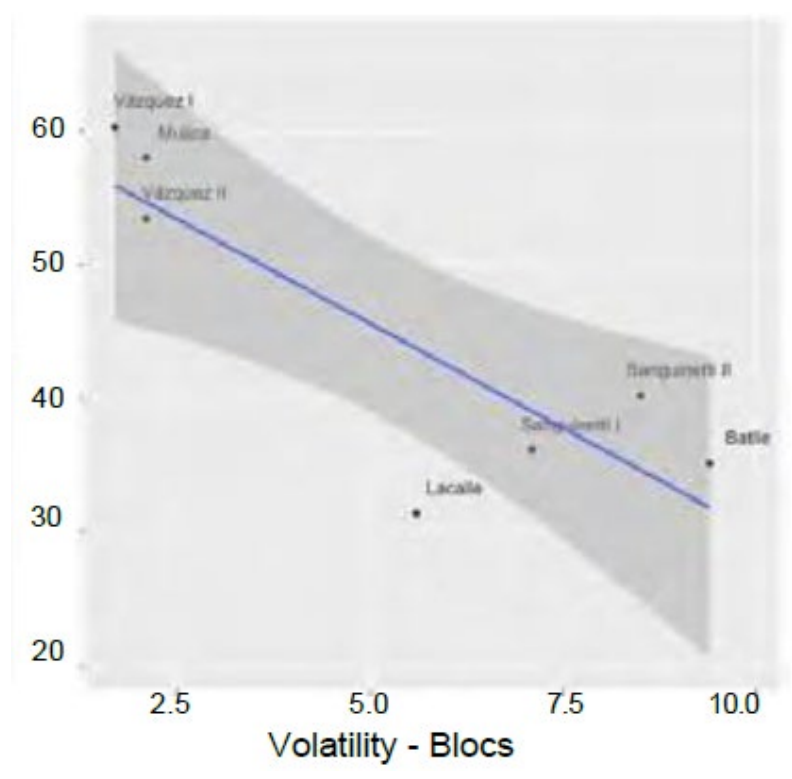

Source: Developed by author, volatility data. Annual approval data correspond to the Executive Approval Project, period 1986-2016, averaged by government period. 
TABLE 2

EFFECTIVE NUMBER OF PARTIES AND VOLATILITY IN URUGUAY 1984-2014

\begin{tabular}{lllllllll}
\hline & & 1984 & 1989 & 1994 & 1999 & 2004 & 2009 & 2014 \\
\hline \multirow{2}{*}{ NEP } & Legislative & 2.65 & 2.96 & 3.33 & 3.3 & 3.07 & 2.39 & 2.65 \\
& Party & 5.7 & 13.4 & 11.5 & 9.9 & 24.8 & 7.6 & 4.2 \\
\multirow{2}{*}{ Volatility } & Bloc & 4.9 & 7.1 & 5.6 & 8.5 & 9.4 & 1.7 & 2.1 \\
\hline
\end{tabular}

The effective number of parties in deputies was slightly above 2 since the $1950 \mathrm{~s}$, but this was already changing in 1984 (Table 3) with a sustained growth of the NEP (Effective Number of Parties) exceeding 3 points. The main parties obtained two thirds of the electorate, which, added to the weight and autonomy of their internal factions, made it difficult to keep a government agreement, since many times they unilaterally abandoned the agreed party coalitions.

As a result of the new electoral rules explained above and the logic of political competition, the effective number of parties decreased over time. As Figure 5 shows, clearly, the average approval ratings of administrations increase as the (NEP) decreases. ${ }^{13}$

\section{FIGURE 5 \\ PRESIDENTIAL AVERAGE APPROVAL RATINGS IN THE PERIOD OF GOVERNMENT AND EFFECTIVE NUMBER OF PARTIES NEP}

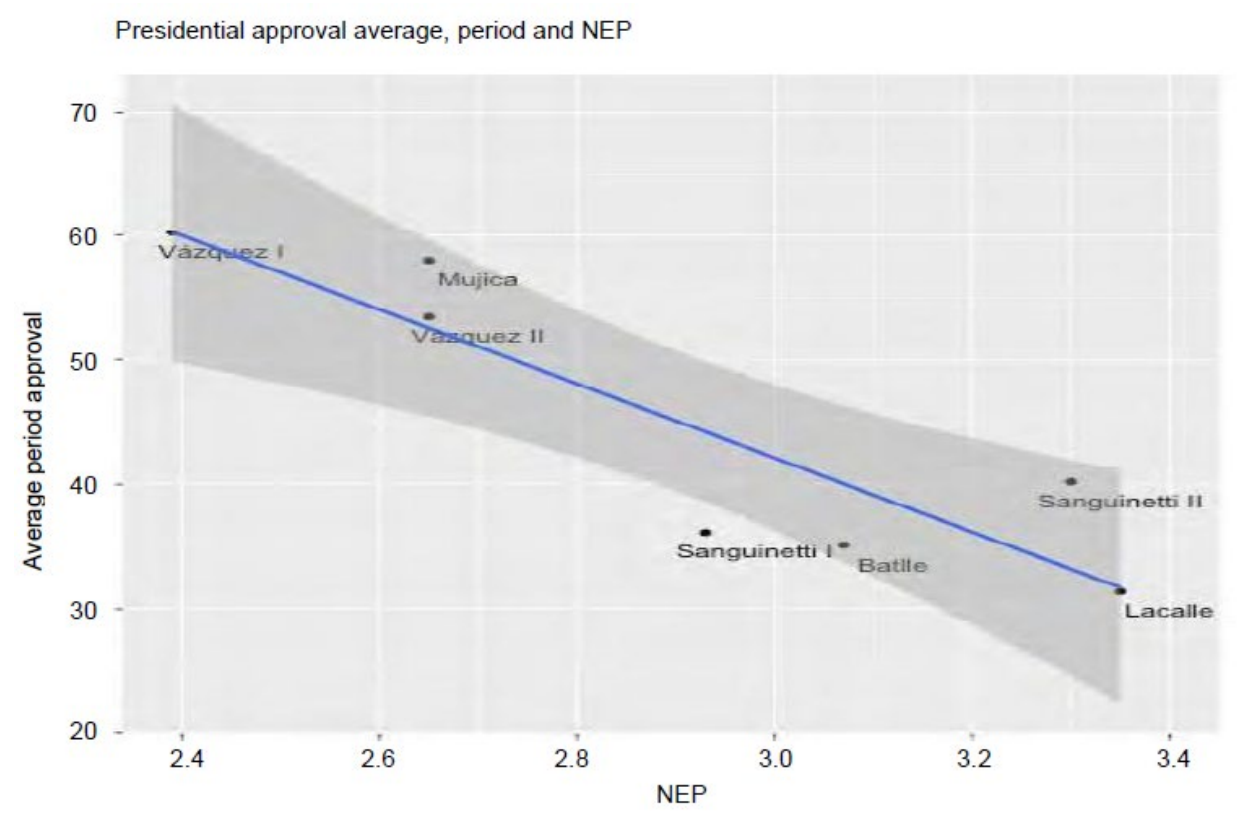

Source: Developed by author, NEP data according to the formula proposed by Laasko and Taagepera 1979 - Prepared by the Political and International Relations Area of the Database of the Social Sciences Faculty - UdelaR. The annual approval data corresponds to the Executive Approval Project period 1986-2016 averaged by government period.

\section{Government Formation and Presidential Approval}

The last decades have witnessed different ways of achieving governance in the country. Sanguinetti's first administration did so as a minority party, establishing specific agreements with the National Party. During the following period, the National Party attempted to create a majority coalition that lasted only one year, after which Colorado and Nationalist sectors progressively abandoned the agreement and began to govern with a minority coalition until the end of the term. The following Colorado government of Julio María Sanguinetti did manage to build a coalition of legislative majorities with the National Party that 
persisted throughout the period. The next Colorado government of Jorge Batlle began with a majority coalition, but it collapsed around the economic crisis of 2002, and ended its term as a minority government. The following Broad Front governments were governments with their own majorities in parliament. (Chasquetti, 2013: 69).

In terms of presidential approval and governance, as shown in Figure 6, approval ratings in the country are better in those periods in which governments achieve a majority. The construction of these legislative majorities became easier under the new institutional design.

\section{FIGURE 6 \\ QUARTERLY PRESIDENTIAL APPROVAL RATINGS BY TYPE OF GOVERNMENT WITH MINORITY OR PARLIAMENTARY MAJORITIES ${ }^{14}$}

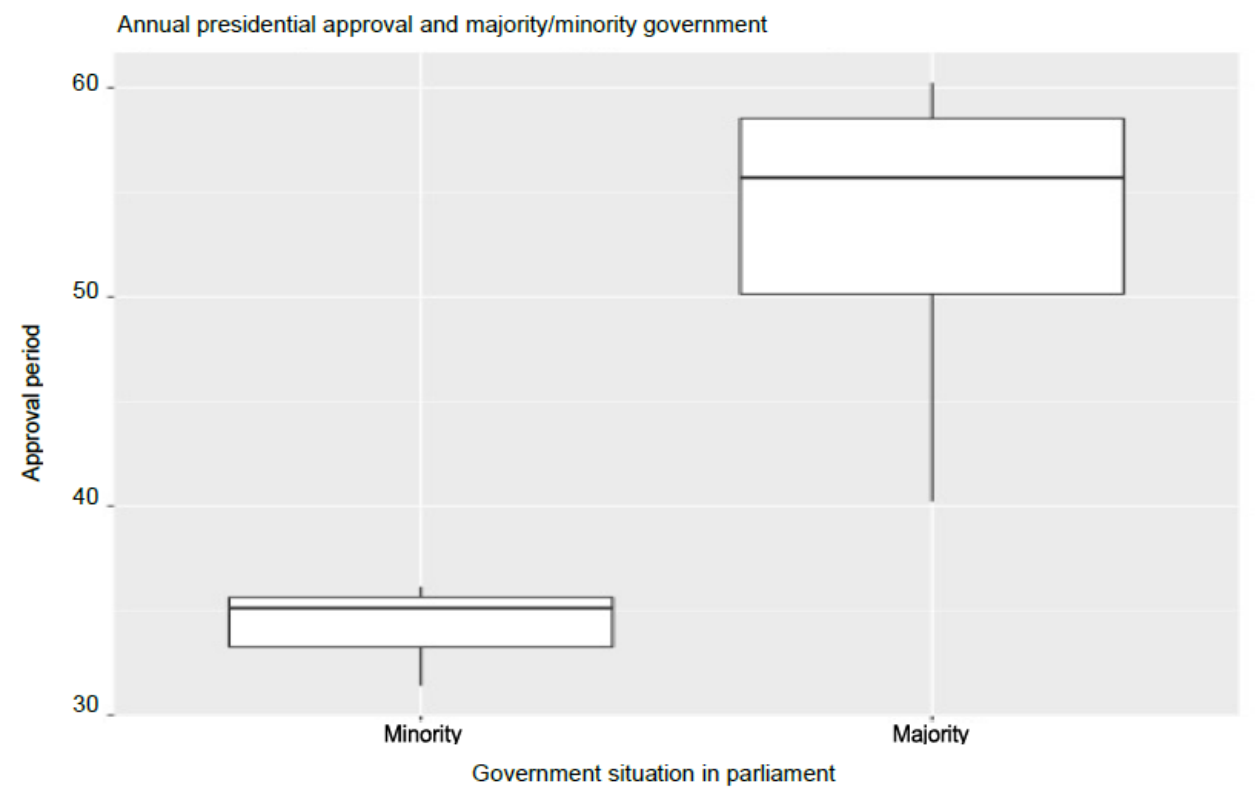

Source: Developed by the author using the distinction between quarters with governments with majorities and governments without parliamentary majorities. Quarterly approval data are from the Executive Approval Project period 1986-2016.

In short, a quick case analysis shows that the institutions from 2000 onwards generated greater popular support for the president and in turn the institutions impacted presidential approval ratings. Specifically, approval is higher when the electoral rules change, requiring the president to have a high threshold to be elected, which alters the initial approval ratings. Regarding the rebalancing of political competition, the data show that in general, approval for post-reform administrations is higher when there is less volatility between blocs, when there are fewer parties in the system and when the president has his/her own legislative majorities.

\section{Institutional Design, Clarity of Responsibility and Presidential Approval Cycles}

A change in institutional design is associated with patterns of presidential approval through its effect on clarity of responsibility. When citizens are able to clearly hold the executive responsible, they will evaluate it according to their opinions regarding the results of government policies, especially in the economic field (Powell \& Whitten, 1992). Thus, "clarity of responsibility" is a concept that allows us to understand the causal mechanism by which institutions are able to affect the approval of presidents. The clarity of responsibility affects both the weight that the economic situation has on approval and the design of electoral preferences based on performance during government administrations and even previous periods. 
Unfortunately, the link between the quality of responsibility and institutional change is presented here as a theoretical assumption, as there is a lack of sufficiently long time series to test through individual attitudes ${ }^{15}$ whether citizens do indeed hold the president more or less responsible before and after institutional changes in Uruguay. For this reason, the empirical analysis of this assumption has not been further explored, but it is supplemented with extensive evidence based on other studies that prove this phenomenon (Rudolph, 2003; León, 2010; Renoò \& Garmacho, 2010).

Assuming, then, this connection between institutions and clarity of responsibility, it is worth asking how the clarity of responsibility can lead to the dynamics of presidential approval adopting a cyclical model. If the institutions grant increased popular support to the president, he/she will start his/her term of office with the phenomenon called "honeymoon" associated to the amount of votes received, but also to the hope that citizens place in a new government (Carlin et al., 2018). The evolution of approval during the period follows the political cycle marked by the limited nature of the presidential term and it is determined by citizens' evaluations regarding the results in different policy areas, especially in economic matters. Thus, at mid-term, a drop in approval is expected, as governments allow themselves to adopt restrictive policies. Similarly, the magnitude of the increase in approval towards the end of the period again depends on the political cycle, as it is associated with the proximity of elections (Stimson, 1991) and the policies that the president promotes to increase the likelihood that his/her party will be reelected (see, e.g., Berlemann \& Enelkemann, 2012).

The literature highlights two main causes of presidential approval through clarity of responsibility: results, on the one hand, and contexts, on the other. Some papers focusing on outcomes point out that it is the effects of the policies implemented that impact approval dynamics. In particular, approval depends on economic performance, as well as international policy results (McAllister, 1999; Sarin \& Villalobos, 2011; Samuels, 2004) and even the declaration of war on third countries in the case of the US. (Mueller, 1973; Powell \& Whitten, 1992:411). Other studies indicate that approval is sensitive to highly visible specific problems such as political or corruption scandals (Mueller, 1970) and acts of violence (Booth \& Seligson, 2009; Carlin et al., 2015b; Newman \& Forchei- mes, 2008; Tavits, 2007). ${ }^{16}$

Those who consider the context argue that the identification of responsibility and its impact on presidential evaluation is conditioned by the president's ability to control the political agenda. These capacities, in turn, are determined by institutional matters such as the powers that the president has regarding the parliament and the ministerial cabinet, the number of parties and their influence in the parliament. (Martínez-Ga- 1lardo, 2001; Calvo, 2007; Carlin et al., 2015 a and b; Rennó \& Gramacho, 2010). In the same direction, other studies warn about other capacities of the president, for example, the way in which the president convincingly manages narratives about the country's policies and problems (Stokes, 2001; Carlin et al., 2015a; Gramacho, 2005), narratives that, in turn, depend on the role played by the media (Pérez-Liñán, 2007) in altering or reinforcing the clarity with which the citizens hold the president responsible.

This article supports the idea that results or outputs matter, but their impact will depend on the institutional and political context, as this is the one that allows for greater or lesser clarity of responsibility. If there is clarity of responsibility, the weight of results, especially economic results, will be critical to understanding changes in presidential support. According to the economic voting theory, the citizen is a rational individual who will take into account the results to evaluate what has been done by the government, disapprove of it and, eventually, change it in the next election (Key, 1968; Dalton, 2000; Anderson, 2000). In this way, management evaluation and electoral decisions are based on the results evaluation, rewarding or punishing the incumbent according to his/her performance in economic matters. The analysis can be based on the prospective or retrospective perceptions of individuals (Fiorina, 1981) or on the aggregate level relationship under the "Macro Polity" perspective (Erickson, MacKuen, \& Stimson, 2002).

As explained in Figure 7, if citizens are not able to hold their president accountable for the government's economic performance, they will be the most important predictors of approval ratings (Powell \& Whitten, 1992). Under this logic, the cyclical dynamics of approval will be conditioned by the restrictive and less popular measures that governments adopt in their mid-term, as well as expansionary policies in the last stage of their term of office (Berlemann \& Enelkemann, 2012; Stimson, 1991). 


\section{FIGURE 7 \\ CAUSAL MECHANISM, INSTITUTIONS, CONTEXT AND PRESIDENTIAL APPROVAL I}

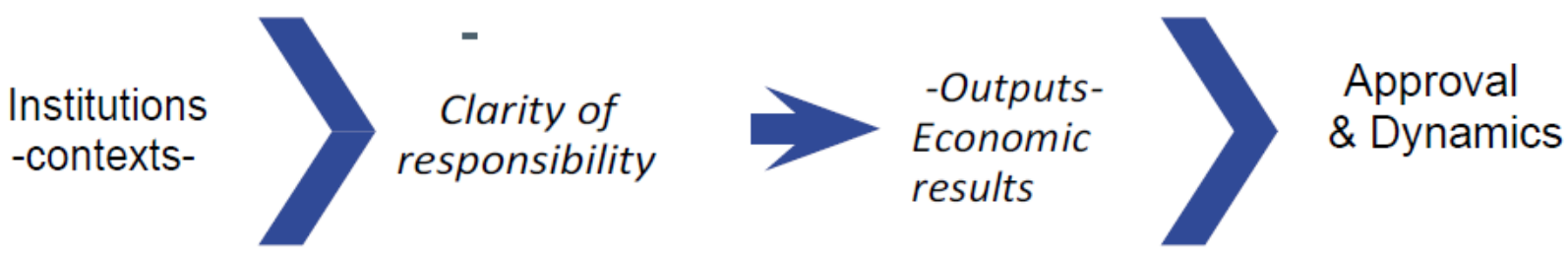

Institutions can then create greater clarity of responsibility and this, in turn, can give greater weight to economic results in approval ratings. But it is also true that at the end of the period citizens will electorally support or punish the governing party according to the results obtained during the period (Key, 1968; Dalton, 2000; Anderson, 2000). Thus, the voting decision depends on repeated evaluations of what the government has done during its administration (Figure 8) and even of previous administrations. Several studies report that those citizens who plan to vote for the president's party evaluate his/her administration much more favorably than those who do not have a defined political preference (Dalton, 2000; Cabezas, 2015; Lebo \& Cassino, 2007). If the results reinforce political preferences, it is possible that the dynamics do not respond directly to the results of the government's economic policies, but rather to the politicalelectoral cycle, where there is greater citizen involvement and interest at the beginning and end of the terms of office, with greater apathy and disinterest during the middle of the period (Goodhart \& Bhansali, 1970).

\section{FIGURE 8 \\ CAUSAL MECHANISM, INSTITUTIONS, CONTEXT AND PRESIDENTIAL APPROVAL II}

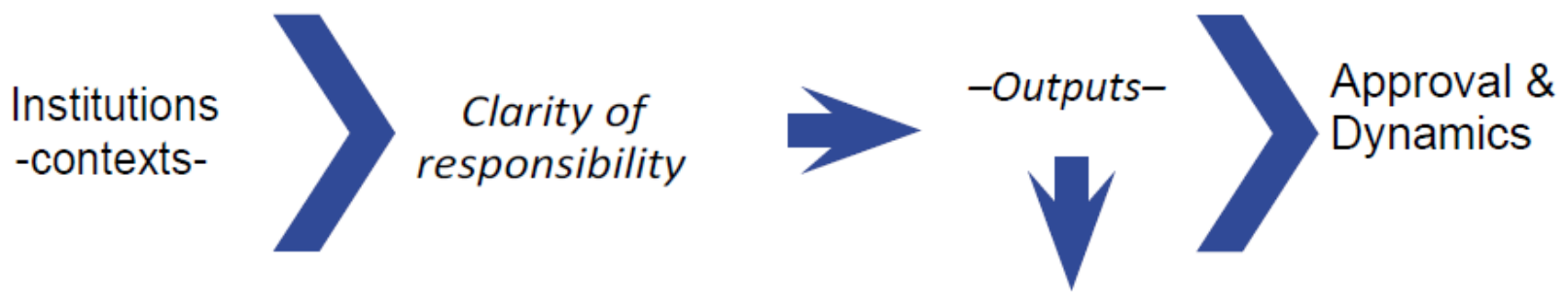

Electoral support

Both phenomena, economic performance and electoral preference, offer empirically linked and logically alternative explanations of presidential approval. Keeping in mind that at an individual level it is difficult to separate the effects on the presidential evaluation regarding the economic situation and the president's electoral support, in the aggregated analysis it is possible to do so. At this level there is a conceptual difference given by the origin and temporal effect of each of these variables, to the extent that at this level it overcomes the collinearity test with the presidential evaluation (see Table 4 in the following section). It is therefore possible to argue that at the aggregated level, the effect of economic performance on approval is reactive and immediate, while the effect of voting is structural and long-term, especially when electoral preferences are stable and the party number is reduced (Holmberg, 2009; Huber et al., 2005).

Previous studies on this subject in Uruguay agree that economic variables are important predictors of presidential evaluation. But, considering that the approval ratings and dynamics have changed since 2000, it makes sense to think that the new institutions have changed the clarity of responsibility. The increase in clarity, in turn, makes the effect of policies, mainly economic, more relevant in this period than in the previous one. 
In order to understand the changes in the dynamics of presidential approval, this paper empirically links the impact of changes in institutional design and approval dynamics, comparing the behavior of economic indicators in both institutional contexts (before and after the changes). It is expected that the greater the clarity of responsibility, the greater the weight of the economic indicators, giving the series its cyclical dynamics.

Hypothesis: After the reform, economic predictors increase their relevance on the evaluation regarding presidential performance, explaining the approval cycles. Alternatively, it could be thought that, given the institutions and the rebalancing of the party system, electoral preferences, associated with long-term outputs, are driving this new cyclical pattern of presidential approval, linked to the electoral cycle.

Alternative hypothesis: In the post-reform moment, partisan identifications have a greater influence on the evaluation of presidents, explaining the approval cycles.

When analyzing the approval evolution in Uruguay, it is important to bear in mind that two circumstances that will be used as control variables in this paper may have an influence. One associated with government attrition or timing, which controls both the attrition of leaders and the mid-term existence of other policies (not necessarily economic), the results of which were not as expected by the citizenry.

The other is direct democracy initiatives. These initiatives can have an impact on management evaluation (Luna, 2002; Altman, 2010), since they provide an alternative mechanism for expressing opinions on a policy implemented by the government. It is, in short, a way of expressing dissatisfaction, so it can be expected to alter presidential evaluation as well (Boelhower, 2018; Luna, 2002). In the Uruguayan case, direct democracy mechanisms aimed at repealing laws (referendums) and those that modify the constitution (plebiscites) have been common in recent history. These initiatives were very frequent, supported by the opposition and mostly successful in the three government administrations that do not follow a cyclical pattern of approval but, after 2000, have declined and have not received the majority support of the citizenry.

Three important absences from the model to be analyzed can be justified. On the one hand, the ("commodity boom") in which the administrations with a cyclical evaluation pattern are taking place is not considered, since the bivariate analysis of approval ratings and GDP growth is included without yielding significant results (See Annex). On the other hand, the fact that the Broad Front administrations have ruled with their own majorities and Batlle's with a broad coalition before the economic crisis that took place during his administration does not assume almost any intra-period variation, since after the institutional change, almost all periods were ruled by a majority and before that by a minority. Finally, the ideological orientation of the government was also not included, since before 2005 all administrations were centerright and from that year until 2015 center-left. In other words, before the reform there is no variation and then there is one center-right and three center-left administrations, which did not provide significant variability, did not impact the results and reduced the consistency of the proposed models.

\section{METHODS AND DATA}

The following analysis is based on quarterly presidential approval (smoothing) data systematized by the Approval Project ${ }^{17}$ as a dependent variable. Indicators of economic situation (VI) could be based on the prospective or retrospective perceptions of individuals (Fiorina, 1981) or on the aggregated level relationship under the "Macro Polity" perspective (Erickson, MacKuen, \& Stimson, 2002). Since we do not have enough long individual series, we opt for the second strategy, using data from quarterly economic indicators of unemployment and inflation from the National Institute of Statistics ${ }^{18}$ and Gross Domestic

Product from the Central Bank of Uruguay. ${ }^{19}$ For electoral support for the president, we use the percentage of voting intention for the president's party recorded by the consulting firm Equipos Mori. ${ }^{20}$ The control variables are the time elapsed since the government took office, measured in quarters, a dichotomous variable that shows the occurrence of instances of direct democracy in the analyzed quarter.

The analytical strategy involved the creation of two time slices in order to determine whether the weight of the dependent variables on approval ratings changes in both contexts through ADL (Autoregressive Distributed Lag) regression models. These stochastic regression models allow trend, seasonal and random 
predictors to be analyzed and overcome the autocorrelation problems associated with time series in other regression models (see Figure 9).

Through the construction of the models it is possible to analyze the magnitude and statistical significance (two-tailed) of the independent variables before and after the reform, including or excluding voting intention in the analysis, in order to observe how the economic and political contexts operated on presidential approval. Finally, in order to explore the relative weight of each variable on presidential approval in general and in different contexts, the table with the betas coefficients and their significance is provided.

\section{FIGURE 9}

\section{CUMULATIVE DECOMPOSITION OF TIME SERIES, QUARTERLY EVALUATION ${ }^{21}$}

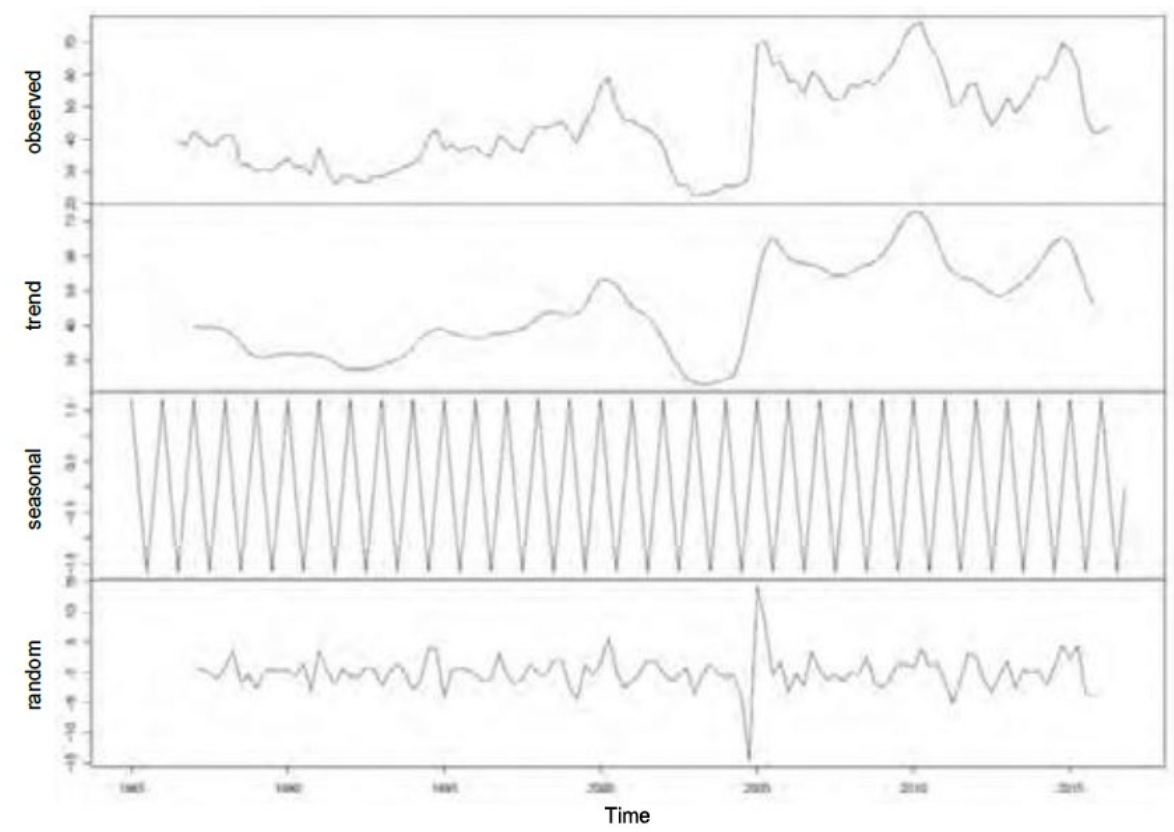

In the specification of the models, the economic variables have been lagged: their effect has been delayed. Thus, the approval is a reaction to the variation of the economic indicator in the previous quarter. The same is true for the voting percentage for the president's party. Support in the previous quarter or at time t-1 will be relevant in explaining approval in the following quarter. The other variables introduced in the model were not lagged because their effect is considered to be concurrent with the approval rating. This applies to the case of government time or timing and direct democracy consultations. In other words, if there are causes related to government attrition, their impact is registered jointly, similar to the holding of a popular consultation such as a plebiscite or referendum. 
TABLE 4

CORRELATION MATRIX AND COLLINEARITY TEST (TEMPORARY VARIABLES)

\begin{tabular}{|c|c|c|c|c|c|c|}
\hline Inflation Unemployment $\mathrm{Gr}$ & owth & & & $\begin{array}{l}\text { \% Voting the } \\
\text { president's } \\
\text { party }\end{array}$ & $\begin{array}{l}\text { Government } \\
\text { time }\end{array}$ & $\begin{array}{l}\text { Demo } \\
\text { Direct }\end{array}$ \\
\hline Inflation & 1 & -0.21 & -0.64 & -0.32 & -0.05 & 0.04 \\
\hline Unemployment & -0.21 & 1 & 0 & -0.03 & -0.10 & -0.02 \\
\hline Growth & -0.64 & 0 & 1 & 0.30 & -0.01 & 0.00 \\
\hline $\begin{array}{l}\% \text { Voting } \\
\text { intention for the president's } \\
\text { party }\end{array}$ & -0.32 & -0.03 & 0.30 & 1 & 0.08 & -0.08 \\
\hline $\begin{array}{l}\text { Government } \\
\text { Time }\end{array}$ & -0.05 & -0.10 & -0.01 & 0.08 & 1 & 0.38 \\
\hline Demo Direct & 0.04 & -0.02 & 0.00 & -0.08 & 0.38 & 1 \\
\hline $\begin{array}{l}\text { Variance inflation factor } \\
\text { (VIF) test }\end{array}$ & 3.62 & 2.60 & 4.27 & 1.16 & 1.28 & 1.21 \\
\hline Variance inflation factor & 1.18 & -- & 1.07 & 1.14 & 1.20 & 1.19 \\
\hline
\end{tabular}

On the other hand, it should be noted that, in order to build the models, the growth variable was eliminated because it presented strong collinearity (Table 4) reaching more than 4 points in the variance inflation factor (VIF) test, and because the theory gives priority to unemployment and inflation, these being better predictors of approval in the country (Luna, 2002). Without this variable, the VIF test shows acceptable levels to avoid collinearity between the variables introduced in the model.

The table shows the weak association between vote and time in government and the low relationship between vote and economic indicators, which supports the idea of the long and short term discussed in the previous section, which supports the decision to separate their impact in this analysis.

\section{Analysis}

Several studies indicate that the economy has been the main explanation for presidential approval ratings in Uruguay. Although we have not explored the alternative hypothesis on electoral preferences or controlled for trend, seasonality and random effects that alter the possible time series findings, we have not seen what happened to the indicators under the two institutional contexts described. Considering that there has been a change in the country's institutions that affects the clarity of responsibility together with a change in the approval dynamics, it is essential to analyze their behavior at both moments.

The first analytical exercise involves the bivariate treatment of the indicators to observe their behavior in the two contexts. The results found in the Annex indicate that GDP growth always tends to increase quarterly approval, so the economic prosperity of the last few years would not seem to alter the relationship. However, inflation marks a different behavior in each of the contexts. Before the institutional changes, CPI growth was more strongly related to approval ratings than in the later period. Unemployment appears to be associated with approval in the moments following the institutional change and, strikingly, correlated inversely under the old institutions: the higher the unemployment, the higher the presidential approval. ${ }^{22}$ 
Finally, the voting intention for the president's party appears as an almost perfect predictor only under the new institutional context, being irrelevant in the previous institutional context.

Bivariate regression helps to clarify the individual incidence of each indicator, but it can hide spurious relationships that do not allow us to see the true impact of the variables on presidential approval. As previously justified, GDP was removed from the analysis and other control variables were also included. The results of $4 \mathrm{ADL}$ regression models are presented below. The figure on the left shows the models before the institutional reform and the one on the right shows the models after it. Two models are displayed in each of them: one shows the coefficients and the standard deviation of the economic variables, controlled by variables of political attrition and direct democracy. And in the other, the voting intention percentage for the governing party is added, fulfilling the proposed alternative hypothesis.

Under the old institutional context (left side), inflation is the variable that has the greatest impact on approval ratings. In this period, the higher the inflation, the lower the approval rating. As could be predicted from the bivariate analysis, unemployment does not appear to be a good predictor of the presidential evaluation evolution. Another finding that is consistent with previous studies is that approval ratings in this period are affected by instances of direct democracy, but in this case by increasing the presidential approval rating. Finally, when the model is controlled for voting intention, the results are not altered and, clearly, electoral preference and political timing are irrelevant variables to explain the variations in presidential approval ratings under the old institutional context.

\section{FIGURE 10 \\ BEFORE AND AFTER MODELS WITH AND WITHOUT VOTING INTENTION FOR THE GOVERNING PARTY ON PRESIDENTIAL APPROVAL BEFORE AND AFTER THE INSTITUTIONAL CHANGE}

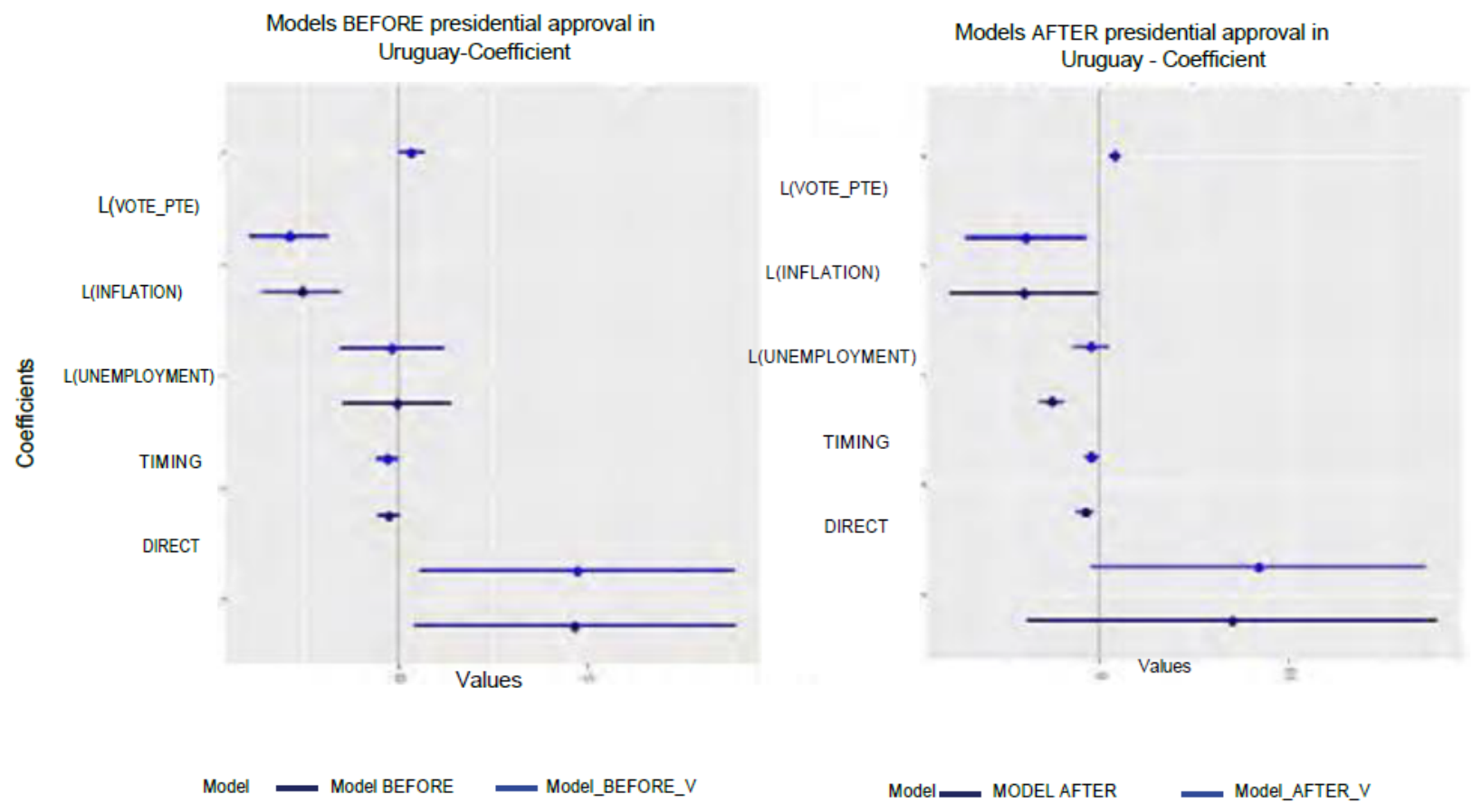

In the models after institutional change (on the right side of the figure), the results show that, without taking into account voting intention, inflation is not related to presidential approval, nor is it related to levels of direct democracy. This model shows that the variation in approval is determined by the variation in unemployment and the timing of the political cycle. However, when voting intention is included, the incidence of the variables changes. In this case, the voting intention variable, together with inflation, are 
good predictors. With this voting intention control, timing and the relevance of unemployment disappear as predictors of changes in the evaluation of the presidential administration.

In conclusion, the results indicate that prior to the institutional changes, approval was subject to inflation, a policy less controlled by the governments of countries such as Uruguay with an economy subject to external variations in exchange rates and international prices. However, variables that could be linked to the direct responsibility of the government (such as unemployment policies) or even political timing had no impact. Perhaps, the emergence of direct democracy instances, which were frequently promoted in that period by the opposition to the government, focused the attention on the president, who was usually the figure who concentrated the defense of the law to be modified. In this context of changing electoral preferences, together with the existence of multiple candidates per party and coalition partners, voting intentions were not associated with the presidential evaluation.

But why did the approval dynamics change in Uruguay, adopting a cyclical approval model after the institutional change?

After the reform, the results show greater variables associated with the evolution of presidential approval, both the incidence of unemployment and political timing justify the cyclical adoption of the approval series, focused on the outputs or results of the administration. As an alternative, if voting intention is considered together with the impact of inflation, it also allows us to think that the cycle may be driven by the electoral cycle, with greater support at the beginning and end of the term and subject to dissatisfaction and indecision in the middle of the period. Obviously, the new electoral rules and the stabilization of political competition may justify this way of thinking about the cyclical approval dynamics.

In short, as was proposed in the hypotheses, the models show that the incidence of economic policies of greater government control, political and electoral times increase under the new electoral context.

\section{What the Case Has Left Us and What It Has in Store for Us}

The presidential approval series in Uruguay since the reopening of democracy has been changing. In addition to the institutional changes introduced in the 1997 Constitution and the new balance of the party system, the series increased their average and the evaluation patterns became cyclical due to the weight that the evaluation of economic results, government timing and the electoral cycle acquired as a consequence of these institutional changes.

According to the evidence provided, the change of electoral rules in Uruguay has made it clearer for citizens to hold the executive branch responsible for the results of the policies carried out by their government (Powell and Whitten, 1992). The change in electoral regulations and the stabilization of competition in Uruguay gave greater "clarity of responsibility" to citizens and, therefore, the variation in approval predictors allows us to understand the causal mechanism by which approval dynamics became cyclical.

In the Uruguayan case, the appearance of the honeymoon, based on the broad electoral support that the presidential candidate requires after the reform, together with the decrease of veto players and the control of the parliamentary majorities, allows a greater initial identification of the citizens with the president, and especially a good clarity to hold him responsible for the country's progress. Thus, the results of economic policies and electoral political timing create the typical cyclical model of approval that characterizes presidential systems. The analysis also leaves open doors for future research. In economic matters, for example, the findings allow us to think about the extent to which inflation, in the context of a country with a dependent economy, can be associated with a cycle of policies totally controlled by the government, which allows us to reflect on the convenience of applying the idea of economic voting and clarity of responsibility in the context of developing countries. But it is also important to point out that, although both unemployment growth and inflation have always been associated with management evaluation, in the case studied, the "commodity boom" and the boom period allowed last governments to maintain a less fluctuating monetary policy and attract investments to the country, which generated a higher price control and lowered unemployment.

Another finding of this paper highlights the importance of the stability of partisan preferences as a result of cumulative, less volatile evaluations, which offer an explanatory alternative to approval cycles, more 
related to political identities than to short-term policy results. The relationship between approval and the government's ideology should be problematized. Powell \& Whitten (404: 1992) state that unemployment is a more important predictor for evaluating the performance of left-wing governments and inflation control for right-wing governments. While this statement may leave a window open for future research, it is certain that, when left-wing (post-reform) governments predominated, inflation does not disappear entirely in the models. And that in the past, with center-right governments, unemployment headed the list of the country's most important problems. ${ }^{23}$ Therefore, this does not seem to be the reasonable explanation for what has happened in the country; in contrast, as has been shown, the changes in the predictors of presidential approval have been modified by the institutional contexts, associated with a greater responsibilization of the citizenry for economic results in general, timing and the electoral cycle. Not because of the policies that citizens expect according to the ideological orientation of the government.

This article is being completed at the dawn of the 2019 election campaign and the end of the commodity boom era. Analysts argue that the next government must form coalitions to obtain legislative majorities in less favorable international economic conditions. These two conditions, the end of the economic boom and possible changes in the style of government, may alter many things, but probably not the clarity of the responsibility that the citizens have towards the president, due to the current electoral regulations, which will allow him to have his honeymoon and be responsible to all the coalition partners. The next presidents under this institutional context will find it difficult to dilute responsibilities in the face of economic results and the timing of government and the electoral cycle will probably continue marking the cyclical pattern of presidential approval in Uruguay.

\section{ACKNOWLEDGEMENTS}

I especially want to thank Ryan Carlin for encouraging me to write this article. Thanks to Cecilia Martínez-Gallardo for her patient assistance, to Fabricio Carneiro, Germán Bidegain and Daniela Vairo, and to the reviewers for their helpful comments and advices. To all of them my thanks and the mistakes are all mine. This paper was performed, thanks to the financial support of CSIC - UdelaR at APSA Annual Meeting 2018. On the panel: "Understanding Public Support for Executives in Different Democratic Systems". The comments of all the attendees, especially those of commentator Aníbal Pérez Liñán and Jonathan Hartlyn, were very helpful. Some are described here and others will be used for further work in the future.

Translated \& edited by American Publishing Services (https://americanpublishingservices.com/).

\section{ENDNOTES}

1. The most appropriate translation would be "clarity for making responsible"; however, in the Spanish literature the concept is referred to as "claridad de responsabilidad" or "claridad de la responsabilidad".

2. The opinion is shared that further experimental analysis can more conclusively test the thick description and assumptions advocated in this paper.

3. For this first term, there is no information available for the first year of government, but it is possible to think that it did not have a honeymoon either, as happened in the following administrations.

4. During Jorge Batlle's administration, the country suffered a strong economic crisis and payment recession, high levels of unemployment, inflation and distrust in the financial system. As a result, the lean approval ratings, which began very well, suffered a significant drop that affects the overall average for the period. However, like the others since then, approval ratings rose at the end of the term.

5. In the long-term analysis of presidential approval, it is inflation but not unemployment that has an influence (Luna, 2002:147).

6. For example. It cut the deadlines that the Legislative Branch had for the treatment of urgent laws and established special majorities to lift presidential vetoes; therefore, it concentrates a little more power in the Executive Branch. It also made the appointment of ministers and secretaries more flexible with the authorization of the Senate, which could allow the president to redesign a new majority in Parliament if he remains in a minority in it, offering ministerial positions to the opposition. 
7. The local dimension is hierarchized in this constitution with the creation of departmental party bodies, administrative decentralization and separation of national and departmental elections.

8. It should be clarified that in Uruguay the president is elected on the same list with the vice-president of the Republic, which is why it is called an electoral formula.

9. The reform also eliminated the accumulation by sub-mottos in the pluri-personal bodies, specifically eliminating the triple simultaneous vote at the level of deputies, thus reducing the number of ballot papers presented for election, but not the system's fractionalization (Piñeiro, 2004). However, it has been stated that the reform did have the effect of reducing the number of parties in the system by generating a single candidate for all sectors and concentrating the competition in the two political blocs.

10. See data in the Political and International Relations Database of the Social Sciences Faculty. University of the Republic.

11. First election after 12 years of military dictatorship, which began in 1973.

12. Inter-party and bloc volatility: amount of electoral variation between political parties and, on the other hand, between political blocs in the election of the period of government. Prepared by the Political and International Relations Area of the Database of the Social Sciences Faculty - UdelaR.

13. Excluding again the Batlle administration for the reasons already mentioned.

14. Majorities: If the government governed with its own parliamentary majorities or coalition. Assumes 1 in quarters where the government had a majority and 0 where it did not. The data was developed by the authors based on Chasquetti, 1998.

15. The questions concerning who is mainly responsible for the country's problems, specifically to what extent the president is responsible, which are available in Latinobarómetro or Lapop, do not cover the two periods to be studied.

16. In Uruguay, cases of corruption and scandals involving the Executive Branch have not been relevant in the period studied. In fact, international ratings highlight it as a case with low levels of corruption and no scandals involving the presidents of these administrations are found (Carlin et al., $2015 \mathrm{~b}$ ). On the other hand, in terms of foreign policy, given the economic and political dimensions of the country, its positions do not have an impact on public opinion.

17. Period of time 1986 third quarter through 2016 second quarter.

18. Systematized by the Sociodemographic Area of the Data Base of the Social Sciences Faculty, University of the Republic. Data available for the whole period.

19. Collected thanks to the Economic Area of the Data Base of the Social Sciences Faculty.

20. Available from the second half of 1989 covering only six months of the first Sanguinetti administration.

21. The very low approval ratings of the trend in 2002 correspond to the worst moments of a serious economic and financial crisis that the country went through. The 2005 peak in random effects corresponds to the government change after the crisis and the first Broad Front government.

22. The data discussed do not entirely match previous findings; however, the lagged analytics used show that, in that period, the higher the unemployment, the higher the presidential approval. This is reversed under the new institutional context. Perhaps the lack of clarity for assigning responsibility may be, in the preceding period, a way of explaining this strange finding.

23. See data at Latinobarometro.org. Main problem of the country.

\section{REFERENCES}

Altman, D. (2010). Direct Democracy Worldwide. Cambridge: Cambridge University Press.

Anderson, C.J. (2000). Economic Voting and Political Context: A Comparative Perspective. Electoral Studies, 19, 151-170.

Anderson, C.J. (2007). The End of Economic Voting? Contingency Dilemmas and the Limits of Democratic Accountability. Annual Review of Political Science, 10, 271-296.

Berlemann, M., \& Enkelmann, S. (2012). The Economic Determinants of U.S. Presidential Approval - A Survey. Working Paper Series in Economics 272, University of Luneburg, Institute of Economics.

Boelhower, D. (2018). Aprovação presidencial (1996-2015) na América Latina: mais participação pode ser uma saída quando a economía vai mal. Revista de Ciências Sociais (UFC) no Dossiê Os Significados das Novas Quedas Presidenciais na América Latina, 49(1), 134-165. 
Booth J.A., \& Seligson, M.A. (2009). The Legitimacy Puzzle in Latin America: Political Support and Democracy in Eight Nations. New York: Cambridge University Press.

Buquet, D., \& Piñeiro, R. (2014). La consolidación de un nuevo sistema de partidos en Uruguay - The Consolidation of a New Party System in Uruguay. Debates, 8, 127-148.

Butler, D., \& Stokes, D. (1969). Political change in Britain. St. Martin's Press, 1971.

Cabezas, J.M. (2015). Aprobación presidencial en América Latina, 2010- 2012. Voto Económico y preferencias políticas. Política. Revista de Ciencia Política, 53(1), 15-35.

Calvo, E. (2007). The Responsive Legislature: Public Opinion and Law Making in a Highly Disciplined Legislature. British Journal in Political Studies, 37(2), 263-280.

Carlin R., Martínez-Gallardo, C., \& Hartlyn, J. (2012). Executive Approval Dynamics under Alternative Democratic Regime Types. In D. Chalmers \& S. Mainwaring (Eds.), Problems Confronting Contemporary Democracies: Essays in Honor of Alfred Stepan. South Bend: University of Notre Dame Press.

Carlin, R., \& Hunt, K.H. (2015). Peasants, Bankers, or Piggbankers? The Economy and Presidential Popularity in Uruguay. Revista de Ciencia Politica, 53(1), 73-93.

Carlin, R., Love, G., \& Martínez-Gallardo, C. (2015a). Security, Clarity of Responsibility, and Presidential Approval. Comparative Political Studies, 48. DOI: 10.1177/0010414014554693

Carlin, R.E., Hartlyn, J., Hellwig, T., Love, G.J., Martínez-Gallardo, C., \& Singer. M.M. (2018, July 1). Public Support for Latin American Presidents: The Cyclical Model in Comparative Perspective. Research \& Politics, 5(3). https://doi.org/10.1177/2053168018787690

Carlin, R.E., Love, G.J., \& Martínez-Gallardo, C. (2015b). Cushioning the Fall: Scandals, Economic Conditions, and Executive Approval. Political Behavior. DOI 10.1007/s11109-014- 9267-3

Chasquetti, D. (1998). Compartiendo el gobierno: multipartidismo y coaliciones en el Uruguay (19711997). Revista Uruguaya de Ciencia Politica, (10), 25-45.

Chasquetti, D. (2013). Cabinets and Legislative Cartels in Uruguay: Examining the Legislative Consequences of Government Formation. Journal of Politics in Latin America, 5(1), 67-94.

Dalton, R. (2000). The Decline of Party Identification. In R.J. Dalton \& M.P. Wattenberg (Eds.), Parties without Partisans: Political Change in Advanced Industrial Democracies. Oxford, UK: Oxford University Press.

Erikson, R.S., MacKuen, M., \& Stimson, J.A. (2002). The Macro Polity. New York: Cambridge University Press.

Fiorina, M.P. (1981). Retrospective Voting in American National Elections. New Haven: Yale University Press.

Goodhart, C.A.E., \& Bhansali, R.J. (1970). Political economy. Political Studies, 18, 43-106

Gramacho, W. (2005). Ciclos de información y funciones de popularidad: El período Cardoso en Brasil (1995-2002). Desarrollo Económico, 45(177), 99-121.

Holmberg, S. (2009). Partisanship Reconsidered. The Oxford Handbook of Political Behavior, pp. 557570. 10.1093/oxfordhb/9780199270125.003.0029

Huber, J.D., Kernell, G., \& Leoni, E.L. (2005). Institutional Con- text, Cognitive Resources and Party Attachments across Democracies. Political Analysis [online], 13(4), 365-386. doi:10.1093/pan $/ \mathrm{mpi025}$

Key, V.O. (1968). The Responsible Electorate: Rationality in Presidential Voting, 1936-1960. New York: Vintage Books.

Lebo, M., \& Cassino, D. (2007). The Aggregated Consequences of Motivated Reasoning and the Dynamics of Partisan Presidential Approval. Political Psychology, 28(6), 719-746.

León, S. (2010). Who Is Responsible for What? Clarity of Responsibilities in Multilevel States: The Case of Spain. European Journal of Political Research, 50, 80-109. doi: 10.1111/j.14756765.2010.01921.x

Lewis-Beck, M.S., \& Ratto, M.C. (2013). Economic Voting in Latin America: A General Model. Electoral Studies, 32(3), 489-493. 
Luján, D., \& López Burian, C. (2016). El tercer gobierno del Frente Amplio en Uruguay: Supremacía electoral de la izquierda y perspectiva de reformas institucionales. Revista Postdata, 21(1).

Luna, J.P. (2002). Pesimismo estructural o voto económico? Sobre la racionalidad agregada del electorado uruguayo. Revista Uruguaya de Ciencia Política, 13, 123-152.

Mc.Allister, I. (1999). The Economic Performance of Governments. In P. Norris (Ed.), Critical Citizens: Global Support for Democratic Government (pp. 188-203). New York: Oxford University Press.

Mueller, J. (1973). War, Presidents, and Public Opinion. Lanham, MD: University Press of America.

Mueller, J.E. (1970). Presidential Popularity from Truman to Johnson. The American Political Science Review, 64(1), 18-34.

Newman, B., \& Forcehimes, A. (2010). 'Rally Round the Flag' Events for Presidential Approval Research. Electoral Studies, 29(1), 144-154.

O’Donnell, G. (2007). Disonancias: Críticas democráticas a la democracia. Buenos Aires: Prometeo Libros.

Pérez-Liñán, A. (2007). Presidential Impeachment and the New Political Instability in Latin America. Cambridge: Cambridge University Press.

Powell G.B., \& Whitten, G.D. (1993). A Cross-National Analysis of Economic Voting: Taking Account of the Political Context. American Journal of Political Science, 37(2), 391-414.

Przeworski, A., Stokes, S., \& Manin, B. (1999). Democracy, Accountability and Representation. New York: Cambridge University Press.

Renno, L., \& Gramacho, W. (2010). Let's Blame Everyone: Executive and Legislative Evaluations of Economic Performance in Brazil and Chile. Journal of Politics in Latin America, 2(1), 53-78.

Rius, A. (1992). El gobierno, la economía y el hombre de la calle. Revista SUMA 7, Montevideo, pp. 735.

Rudolph, T.J. (2003). Institutional Context and the Assignment of Political Responsibility. Journal of Politics, 65(1), 190-215.

Samuels, D. (2004). Presidentialism and Accountability for the Economy in Comparative Perspective. American Political Science Review, 98(3), 425-436.

Shapiro R.Y., \& Conforto, B.M. (1980). Presidential Performance, the Economy, and the Public's Evaluation of Economic Conditions. The Journal of Politics, 42(1), $49-67$.

Sirin, C.V., \& Villalobos, J.D. (2011). Where Does the Buck Stop? Applying Attribution Theory to Examine Public Appraisals of the President. Presidential Studies Quarterly, 41(2), 334-357.

Stimson, J.A. (1991). Public Opinion in America: Moods, Cycles, and Swings. Boulder, CO: Westview Press.

Stokes, S.C. (2001). Mandates and Democracy: Neoliberalism by Surprise in Latin America. New York: Cambridge University Press.

Tavits, M. (2007). Clarity of responsibility and corruption. American Journal of Political Science, 51(1), 218-229.

Vairo, D., \& Rodríguez, J.R. (2017). Treinta años de democracia en Uruguay: A modo de balance. 


\section{APPENDIX}

\section{PRE-MODEL BIVARIATE CHARTS. APPROVAL OF THE PRESIDENTIAL ADMINISTRATION ACCORDING TO ECONOMIC VARIATION AND VOTING INTENTION FOR THE GOVERNMENT PARTY}

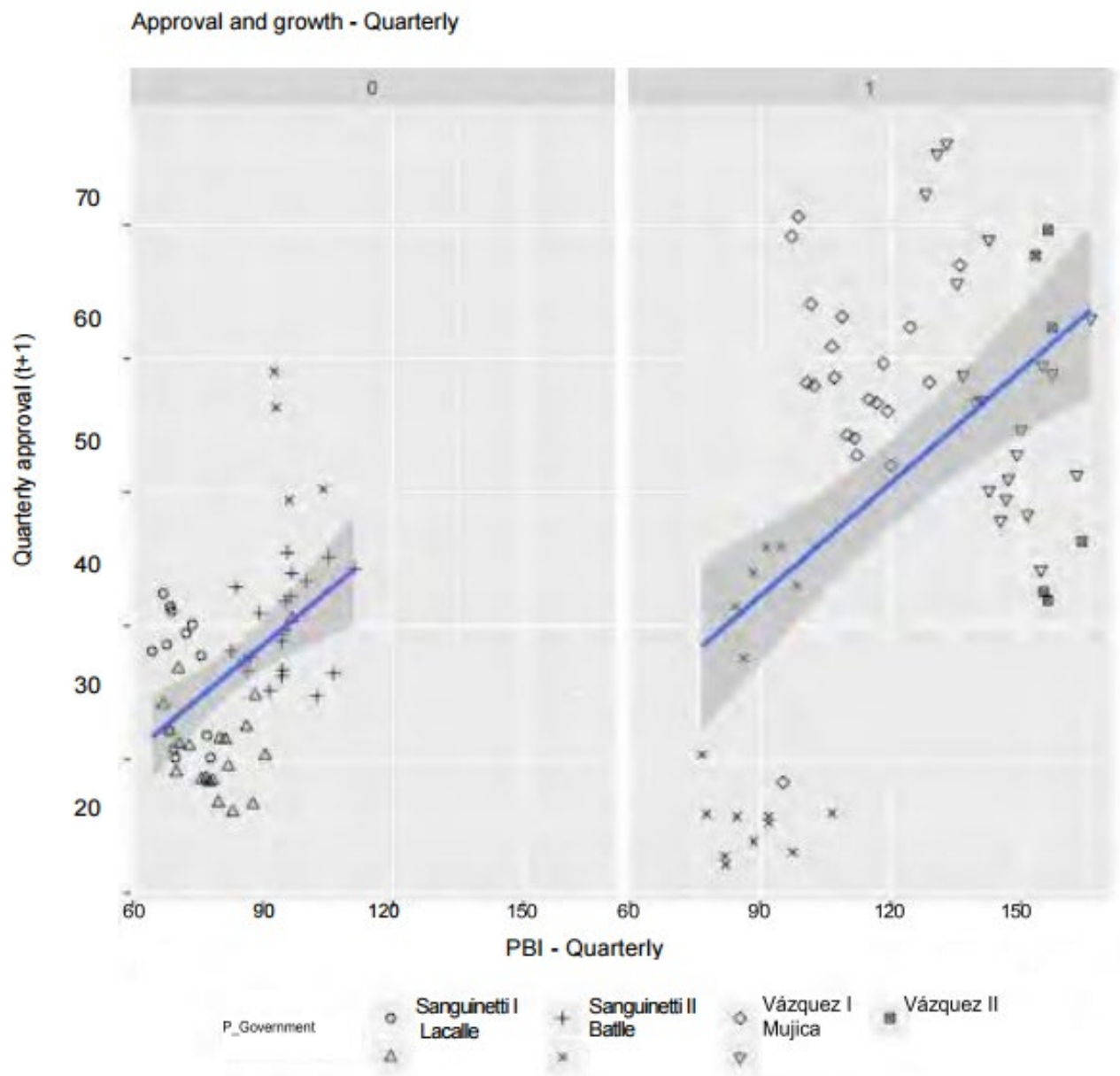



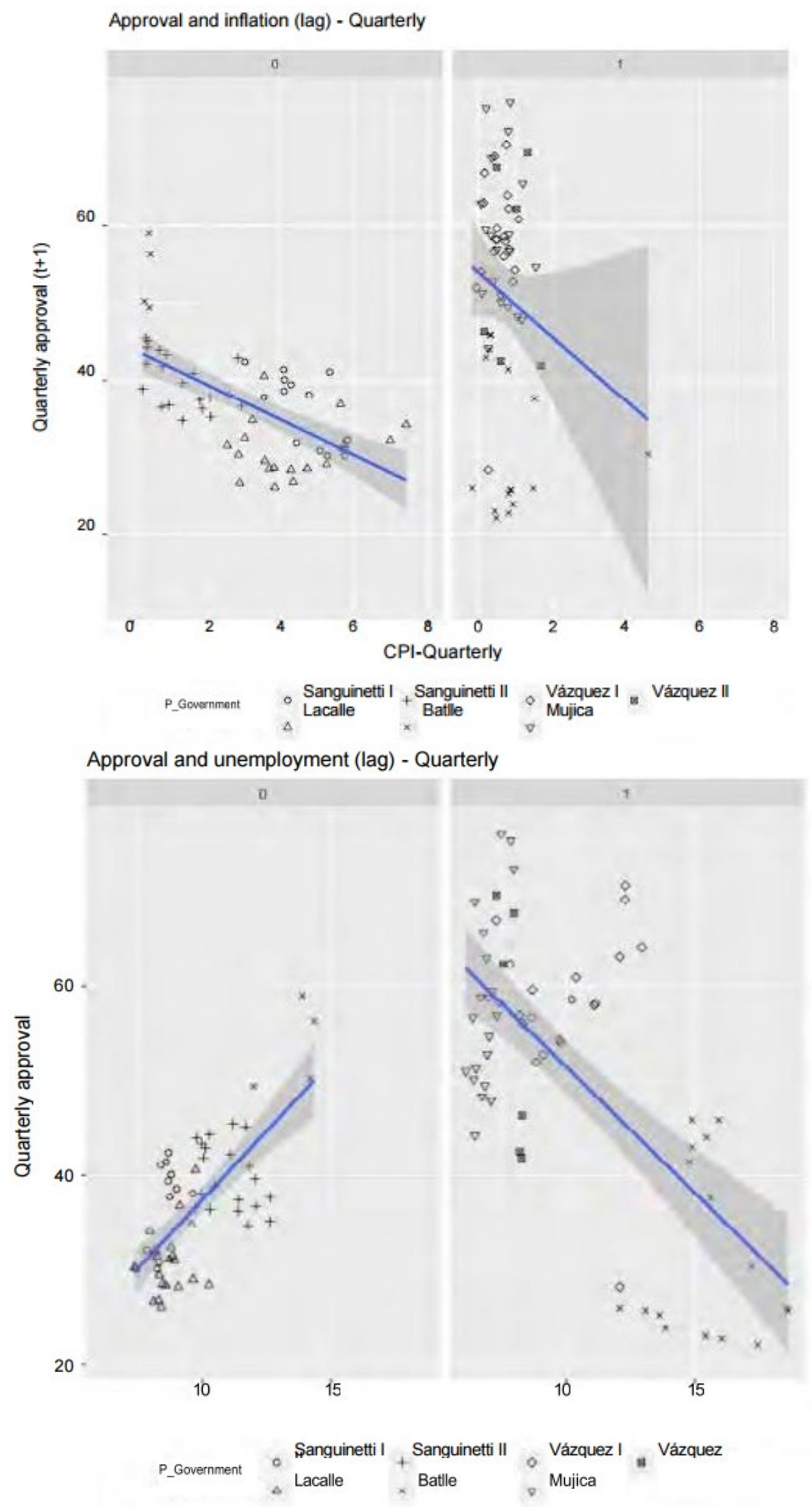

44 Journal of Leadership Accountability and Ethics Vol. 18(5) 2021 
Approval and voting intention for the president's party (lag) - Quarterly

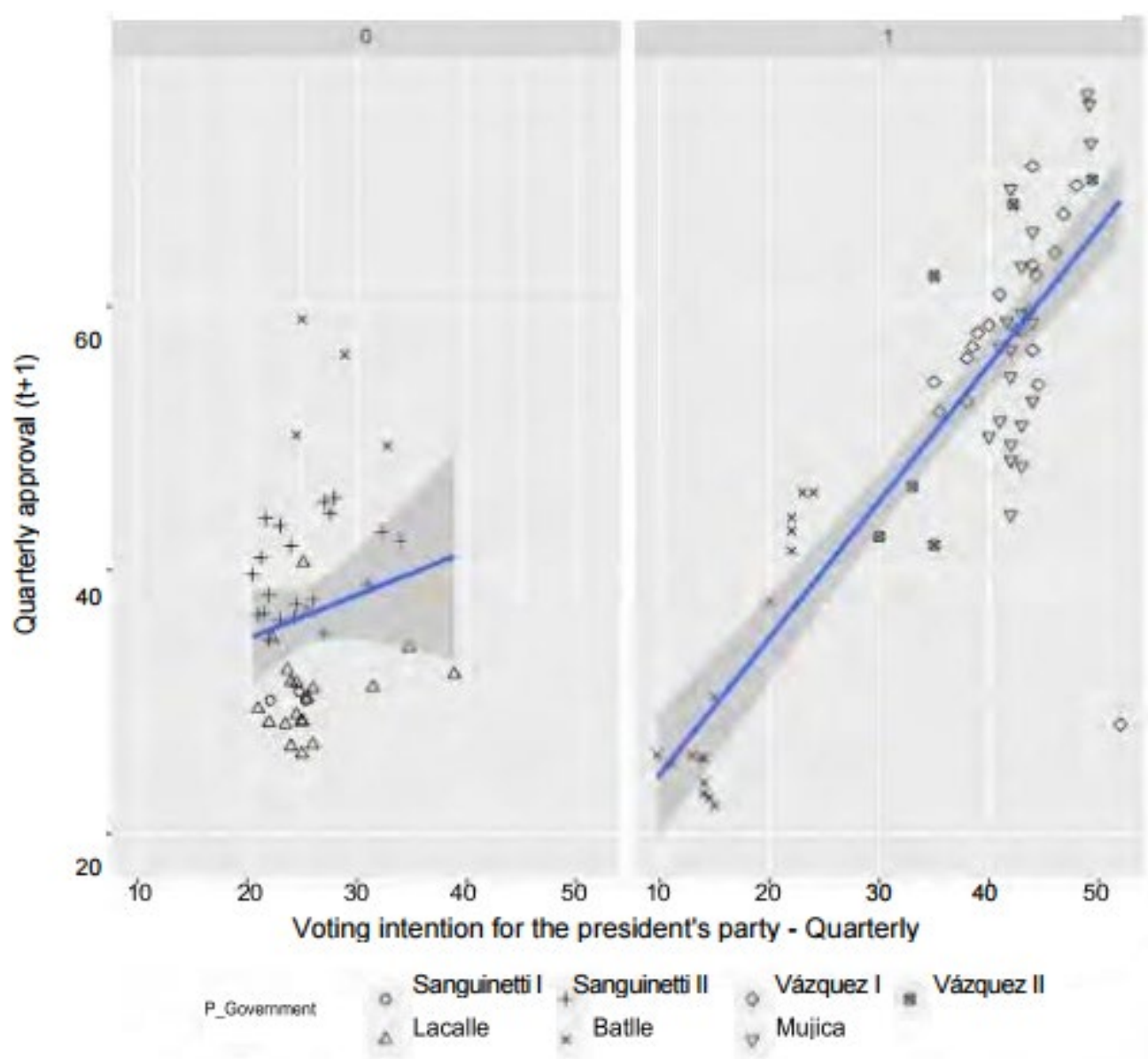

